\title{
Propagation Potentials of Genotypes and Different Physiological Ages of Stem Cuttings in Jatropha curcas L.
}

\author{
A. K. M. Aminul Islam (Corresponding author) \\ Department of Chemical and Process Engineering \\ Faculty of Engineering \& Built Environment \\ Universiti Kebangsaan Malaysia (UKM), Bangi, Selangor 43600, Malaysia \\ Tel: 601-4927-7204Ｅ-mail: aminuljkkp@yahoo.com \\ Zahira Yaakob \\ Department of Chemical and Process Engineering \\ Faculty of Engineering \& Built Environment \\ Universiti Kebangsaan Malaysia (UKM), Bangi, Selangor 43600, Malaysia \\ Tel: 603-8921-6420 E-mail: zahira@vlsi.eng.ukm.my \\ Nurina Anuar \\ Department of Chemical and Process Engineering \\ Faculty of Engineering \& Built Environment \\ Universiti Kebangsaan Malaysia (UKM), Bangi, Selangor 43600, Malaysia \\ Tel: 603-8921-6421 E-mail: drnurina@eng.ukm.my \\ Mohamad Osman \\ Kulliyyah of Science, International Islamic University Malaysia (IIUM) \\ Kuantan 25200, Pahang, Malaysia \\ Tel: 609-571-6759Ｅ-mail: mbopar2004@yahoo.com
}

The research is financed by Universiti Kebangsaan Malaysia, Grant No. UKM-GUP-BTK-07-14-193 (Sponsoring information)

\begin{abstract}
Propagation potentials of stem cuttings of different physiological ages and genotypes of physic nut (Jatropha curcas L.) were studied at UKM, Malaysia. Stem cuttings of the different physiological ages (hardwood, semi hardwood and soft wood) taken from five selected genotypes of Jatropha were planted in soil media (top soil). Data were collected on the attributes of the stem cuttings and then analyzed using computer based software, SAS, version 9.01, (2008). The study showed significant variability in shoot and root development and growth of shoots of the three physiological ages of cuttings and five genotypes. Semi hardwood stem cuttings had lower days to opening of new bud and shooting (4.8 and $11.7 \mathrm{~d}$, respectively) as well as higher percentage of sprouted and rooted cuttings of $100 \%$ and $98.5 \%$, respectively. Soft wood cuttings took more days to opening of new bud and shoot development in all five genotypes. Soft wood cuttings also showed lower percentage of rooted cuttings. Semi hard wood cuttings proved to be more suitable for the vegetative propagation of Jatropha curcas through stem cutting, which gave more than 98\% success. Genotypic differences were observed in shooting and rooting of Jatropha. Genotype JC 14 performed better in all three types of cutting compared to other four genotypes.
\end{abstract}

Keywords: Jatropha curcas L., Biodiesel plant, Vegetative propagation, Stem cutting

\section{Introduction}

Jatropha curcas L., a drought-tolerant, photo-insensitive, perennial plant belonging to the family Euphorbiaceae, 
appears to be a potential source of biodiesel, which has evoked worldwide interest in recent years (Openshaw, 2000 and Pant et al., 2006). In spite of some doubts regarding this species, it appears to hold promise for future as a potential biodiesel plant. Jatropha is a multipurpose tree with a long history of cultivation in tropical and subtropical regions of the world (Catie, 2000 and Henning, 2002). Jatropha plants have profuse vegetative growth, but the number of seeds produced per plant is very low. Besides, the plants produce seeds after approximately 2-3 years depending on environmental conditions and seeds have limited viability, they lose almost 50\% viability within 15 months (Kobilke, 1989). Propagation through seeds leads to genetic variability and makes the plants vulnerable to diseases whereas propagation through vegetative means offers an advantage in developing genetically homogeneous plant material, disease-free varieties for commercial plantings (Nanda and Kochhar, 1987).

Research on propagation of Jatropha is limited. Thus it was considered useful to undertake a systematic study on the vegetative propagation of Jatropha through stem cuttings. On the other hand, the rooting of cuttings is strongly influenced by genotype (Kibbler, et al., 2004). So studies on the effect of genotype and physiological ages of stem cuttings of Jatropha also important and have not been reported yet.

It is needed to develop a vegetative propagation method to ensure genetically pure seed material for commercial plantings. Adventitious root formation has a lot of commercial interests because there are many plant species cutting that are difficult to root. In some plant species, adventitious root formation initiates without any treatment, while others require different growth regulators usually auxin (Syros et al., 2004). Vegetative propagation through stem cuttings without any hormone application can be a profitable and efficient procedure of multiplication of Jatropha curcas. It also helps to retain the heterotic nature of bred seedlings for long time without fear of segregation because there is no further recombination process.

Therefore, the present study was undertaken to develop the appropriate techniques for mass production of seedlings through stem-cutting without any hormones in order to maintain genetic purity, uniformity and gainful exploitation of useful variation, and meet the demand for high-quality planting material at commercial scale.

\section{Materials and Methods}

The present study was carried out at the Glass House, Faculty of Science and Technology, Universiti Kebangsaan Malaysia. Five elite genotypes of Jatropha curcas (seed yield basis) were selected from 487 plant populations collected from diverse eco-geographical regions of Malaysia and six other countries. Healthy and uniform stem-cuttings (12-15 cm in length) of Jatropha curcas were obtained early in the morning and the cuttings were grouped based on their physiological ages. The chosen ages were hardwood (more than a year old) semi-hardwood (current season's growth but fairly matured) and softwood (tender growing stems) (Nanda and Kochhar, 1984; Puri and Verma, 1996; and Evans, 1999). Fifteen cuttings of each treatment were inserted separately into 15 poly bag at $4 \mathrm{~cm}$ depth. Top soil was used as propagation substrate. The experiment was repeated three times for all treatments. After inserting the cuttings, all poly bags were watered at two-day intervals throughout the experimental period.

Observations were recorded on days to new bud opening, days to shoot development, percent cuttings with shoot, percent cuttings with root, number of shoots per cutting, number of roots per cutting, number of leaves per cutting, shoot length $(\mathrm{cm})$, root length $(\mathrm{cm})$ at biweekly intervals up to 45 days. For statistical analysis, the data of percent cuttings with shoot and percent cuttings with root were transformed to $\arcsin \sqrt{ }(100 / X)$; actual percentage are shown in the results. All data were analyzed using SAS statistical package version 9.01 (2008) for ANOVA. Treatments means were compared using Tukey's test at 5\% level of probability (Steel and Torrie, 1980).

\section{Results and Discussion}

Physiological ages of stem cuttings, genotypes and stem cuttings $\times$ genotype interaction showed high significant variation among the studied characteristics (Table 1). Semi hard wood cuttings significantly showed lesser days to new bud opening and days to bud opening compared to other two types of cuttings (Table 2). Significant higher percentage of sprouted and rooted cuttings was observed in semi hard wood cuttings. Hard wood cuttings produced higher number of shoots per cuttings, leaves per cuttings and lower shoot length, whereas semi hard wood produced maximum shoot length, while soft wood cuttings produced more number of roots per cuttings with maximum root length (Table 2). Sprouting on stem cuttings of hard wood and semi hard wood cuttings occurred earlier than soft wood (Table 2). Earlier opening of new bud and shoot development in semi hard wood and hard wood cuttings indicated the presence of growth hormones in the tips of axils ready to shoot, which agrees with the report of Sax (1962) and Gardener (1929). The rapid and higher number of roots per cuttings and root length from softwood in the present study suggested that the presence of higher concentration and influence 
of root promoting substances from the tips of Jatropha curcas stem cutting. The reduced rooting potentials in hardwood may be due to lowering phenolic levels as reported by Hartmann and Kester (1990) in some plant species.

Days to opening of new bud and shoot development were significantly lower in genotype JC 14 as compared to the other genotypes and higher percentage of cuttings with shoots $(100 \%)$, roots $(98.5 \%)$ and number of shoots per cuttings $(4.5)$. The longest shoot $(12.9 \mathrm{~cm})$ and root $(10.4 \mathrm{~cm})$ was also produced by genotype JC 14 (Table 2 ). Genotype JC 17 produced maximum number of roots per cuttings (11.6) and JC 20 produced more number of leaves (8.6) per cutting among the five genotypes (Table 2). The stronger genetic control was also described by Shepherd et al. (2005) on rooting percentage in pine.

Semi hard wood cuttings required significantly $(P \leq 0.01)$ lower number of days to opening of new bud among all the genotypes, while hard wood cuttings required significantly $(P \leq 0.01)$ higher number of days to opening of new bud (Fig. 1). Semi hard wood cuttings of genotype JC 13 required minimum days to shoot development and JC 21 required maximum days (Fig. 2). Genotype JC 14 required minimum days to new bud opening and shoots development compared to other genotypes whereas JC 21 required maximum days (Fig.'s 1\&2).

More than $60 \%$ cuttings produced shoot after 15 days of transplanting (DAP) in all genotypes in all cutting ages and semi-hard wood cuttings of only one genotype (JC 14), which produced $100 \%$ shoot after 15 DAP (Fig. 3 ). Genotypic differences in rooting have been documented in a number of woody Australian species, Acacia baileyana (Schwarz et al., 1999) and Eucalyptus resinifera (McComb and Wroth, 1986). The significant $(P \leq 0.01)$ combined effect of genotype by cutting interaction on days to opening of apical bud and shoot development gave an insight of the selection of right physiological age of cuttings for the propagation of different genotypes (Table 3). Success of rooting of woody stem cuttings, in the majority of ornamental plants and fruit trees depends mainly on the physiological stage of the mother plant (Day and Loveys, 1998).

Hardwood cuttings produced significantly higher number of shoots per cuttings in all genotypes compared to semi-hard and soft-wood cuttings. This implies that the cutting develops more shoots probably because of its higher carbohydrate reserve (Hartmann and Kester, 1990 and Jan, 2001). Rate of shooting was rapid in semi-hard and hard-wood cuttings, while it was prolonged in soft-wood cuttings and extended to 45 days after planting. The hardwood cutting was found to be the best type of cuttings when treated with IBA because it gave the best performance compared to semi-hardwood and soft-wood cuttings of Jatropha curcas (Noor Camellia et al., 2009). Percentage shooting was slow in soft-wood cuttings by 45 days after planting. hard-wood and semi-hardwood cuttings of JC 14 and JC 17 showed significant higher percentage shooting by 15 days after planting. All cuttings from semi-hard wood produced 100\% shoots in all genotypes. Genotype JC 14 produced maximum number of shoots per cutting in all three types of cuttings whereas the least number was produced by JC 21. Hard-wood cuttings of genotype JC 14 produced maximum number of shoots per cutting among all combinations (Fig. 4).

There was incremental progress in the number of leaves per cuttings from 15 to 45 days after planting in all treatments but was maximum in hard-wood cuttings, while soft-wood cuttings produced less number of leaves in all genotypes (Fig. 5). Hard-wood cuttings of genotype JC 21 produced maximum number of leaves per cutting followed by JC 20 and JC 14 after 45 days. Different stem cuttings and different genotypes showed significant variations in their ability to initiate shoot development. Maximum shoot length was observed in genotype JC 14 in all type of cuttings but semi-hard wood cuttings produced the longest shoot (Fig. 6).

The highest percentage of rooted cuttings (avg. 72.4\%) was observed in semi-hard wood cuttings whereas minimum percentage (avg. 55.1\%) was observed in soft-wood cuttings (Table 3) and the same trend continued until 45 days after planting (avg. 98.5\% and 90.7\%, respectively). Soft-wood cuttings showed poor performance or even failed to root after 15 days of planting, which could be due to higher meristematic growth on the top and consequently more endogenous auxins were present in such cuttings. Sprouting of buds took place much earlier than rooting in both species (Fig. 8g) This result showed close agreement with the findings of Sunita et al. (2005). The root formation in some cuttings took much longer and even after one month where they did not have any visible roots and showed only some callusing (Fig. 8).

Number of roots per cutting was very few after 15 days of planting and ranged from 0 to 4 (Table 3 ) and maximum after 30 day (Fig. 8d-f). Semi-hard wood cuttings produced maximum number of roots per cutting and it was 18.7 in JC 21 followed by JC 13 (18.8). Number of roots per cuttings was reduced after 45 days of planting, which might be due to rotting of some roots during development process which was initially developed (Table 3). The highest root length was observed in hard-wood cuttings after 45 days of planting. The increased root development was due to higher food reserve in hard-wood cuttings. Genotype JC 14 produced longer root in hard, semi-hard and soft-wood cuttings (11.0, 10.0 and $10.1 \mathrm{~cm}$, respectively) and minimum in JC 20 (Table 3). 
Semi-hard wood stem cuttings had lower days to opening of new bud and shoot development as well as higher percentage of sprouted and rooted cuttings in most of the genotypes. Similarly, hardwood cuttings showed lesser days to opening of new bud took more days to shoot development. Genotype JC 14 had lower days to new bud opening and shoot development with higher shoots per cuttings, roots per cuttings, leaves per cuttings followed by JC 17. Semi-hard wood cuttings could be the most effective propagation material of Jatropha and genotype JC 14 had potential for vegetative propagation through various types of stem cuttings.

\section{Conclusion}

The present study showed significant variability in root and shoot development and shooting growth (seedlings) of the three physiological ages of stem cuttings. Semi-hard wood and hardwood cuttings had lesser days to opening of new bud and shoot development as well as higher percentage of sprouted and rooted cuttings in most of the genotypes. Semi-hard wood cuttings were the most effective propagation material for Jatropha through vegetative means. Genotype JC 14 had lower days to new bud opening and shoot development with higher shoots per cuttings, roots per cuttings, and leaves per cuttings. It could be considered as easy-to-root upon stem cutting. Vegetative propagation is also possible for Jatropha curcas without using any growth hormones.

\section{Acknowledgements}

The project is financed by the Universiti Kebangsaan Malaysia, under the Grant UKM-GUP-BTK-14-193. The authors would like to thank university authority for financial support.

\section{References}

Catie. (2000). Report Centro Agronomico Tropical de Investigacion y Ensen anza, Costa Rica, vol. 1.

Day, J.S., \& Loveys, B.R. (1998). Propagation from cuttings of two woody ornamental Australian shrubs, Boronia megastigma Nees (brown boronia) and Hypocalymma angustifolium Endl. (white myrtle). Australian Journal of Experimental Agriculture, 38: 201-206.

Evans, E. (1999). Propagation by stem cutting. Instructions for a home gardener.

Gardener, F.E. (1929). The relationship between tree age and the rooting of cuttings. Proc. Am. Soc. Hort. Sci., 26: $101-104$.

Hartmann, H.T., \& Kester, D.E. (1990). Plant Propagation: Principles and Practices. 5th edn. Regents: Prentice Hall, Englewood Cliffs, New Jersey, pp: 662.

Heller, J. (1996). Physic nut (Jatropha curcas L.). Promoting the conservation and use of underutilized and neglected crop, 1. Institute of Plant Genetics and Crop Plant Research, Gatersleben/ International Plant Genetic Resources Institute, Rome.Palgrove, K. C., Trees of Southern Africa, Capetown Struik Publishers (Pty) Ltd.

Henning, R. (2002). IK Notes, vol. 47, World Bank.

Jan Mip Dick. (2001). Thirty years of vegetative propagation research on tropical trees in Scotland in ETFRN News 34/01: 26 -27.

Kibbler, H., Johnston, M.E., \& Williams, R.R. (2004). Adventitious root formation in cuttings of Backhousia citriodora F. Muell - 1. Plant genotype, juvenility and characteristics of cuttings. Scientia Horticulturae, 102: 133-143.

Kobilke, H. (1989). Diploma thesis, University Hohenheim, Stuttgart.

McComb, J.A., \& Wroth, M. (1986). Vegetative propagation of Eucalyptus resinifera and E. maculata using coppice cuttings and micropropagation. Aust. J. For. Res., 16, 231-242.

Nanda, K.K., \& Kochhar, V.K. (1987). Vegetative Propagation of Plants. Principles and Practices, India Book Trust.

Noor Camellia, N.A., Thohirah, L.A., Abdullah, N.A.P., \& Mohd Khidi, O. (2009). Improvement on Rooting Quality of Jatropha curcas Using Indole Butyric Acid (IBA). Research Journal of Agriculture and Biological Sciences, 5(4): 338-343.

Openshaw, K. (2000). A review of Jatropha curcas: an oil plant of unfulfilled promise. Biomass Bioenergy, 19, $1-15$.

Pant, K.S., Khosla, V., Kumar, D., \& Gairola, S. (2006). Seed oil content variation in Jatropha curcas L. in different altitudinal ranges and site conditions in HP, India. Lyonia, 11, 31-34.

Puri, S., \& Verma, R.C. (1996). Vegetative propagation of Dalbergia sissoo Roxb. using softwood and hardwood stem cuttings. J. Arid Environ., 34, 235-245,. 
SAS. (2008). SAS/STAT User Installation Guide for SAS ${ }^{\circledR}$ 9.1.3 Foundation for Microsoft ${ }^{\circledR}$ Windows ${ }^{\circledR}$. SAS Institute Inc., Copyright ${ }^{\circledR} 2003$, Cary, North Carolina, USA.

Sax, K. (1962). Aspects of aging in plants. An. Rev. Plant Physiol., 13: 489-506.

Schwarz, J.L. and Glocke, P.L., \& Sedgle, M. (1999). Adventitious root formation in Acacia baileyana F. Muell. J. Hort. Sci. Biol., 74, 561-565.

Shepherd, M., Mellick, R., Toon, P., Dale, G., \& Dieters, M. (2005). Genetic control of adventitious rooting on stem cuttings in two Pinus elliottii $\times$ P. caribaea hybrid families. Ann. For. Sci., $62403-412$.

Steel, R.G.D., \& Torrie, J.H. (1980). Principle and Procedures of Statistics: A Biometrical Approach. Second Edition, Mc. Graw Hill Book Co. Inc. New York.

Sunita, K., Kochhar, V.K., Singh, S.P., Katiyar, R.S., \& Pushpangadan, P. (2005). Differential rooting and sprouting behaviour of two Jatropha species and associated physiological and biochemical changes. Current Science, 89(6): 936-938.

Syros, T., Yupsanis, T., Zafiriadis, H., \& Economou, A. (2004). Activity and isoforms of peroxidases, lignin and anatomy, during adventitious rooting in cuttings of Ebenus cretica L. Journal of Plant Physiology, 161: 69-77.

Table 1. Analysis of variance for different attributes of stem cuttings influenced by physiological ages of cuttings and genotypes over 45 days after planting in Jatropha curcas

\begin{tabular}{|l|l|l|l|l|l|l|}
\hline Traits & Replication & $\begin{array}{l}\text { Stem } \\
\text { Cuttings }\end{array}$ & Genotypes & SC $\times$ Gen & Error & $\begin{array}{l}\text { CV } \\
(\%)\end{array}$ \\
\hline Degrees of freedom & 2 & 2 & 4 & 8 & 28 & - \\
\hline Days to new bud opening & $0.01 \mathrm{~ns}$ & $24.87^{* *}$ & $8.30^{* *}$ & $1.41^{* *}$ & 0.05 & 3.59 \\
\hline Days to shoot development & $1.36 \mathrm{~ns}$ & $11.96^{* *}$ & $26.16^{* *}$ & $6.02^{* *}$ & 1.15 & 8.71 \\
\hline Percent cuttings with shoot & $0.21 \mathrm{~ns}$ & $236.42^{* *}$ & $140.59^{* *}$ & $93.85^{* *}$ & 0.07 & 0.28 \\
\hline Percent cuttings with root & $0.08 \mathrm{~ns}$ & $234.29^{* *}$ & $195.47^{* *}$ & $90.66^{* *}$ & 0.55 & 0.78 \\
\hline Number of shoots per cuttings & $0.01 \mathrm{~ns}$ & $10.94^{* *}$ & $4.65^{* *}$ & $0.79^{* *}$ & 0.02 & 4.59 \\
\hline Number of roots per cuttings & $0.08 \mathrm{~ns}$ & $10.34^{* *}$ & $6.72^{* *}$ & $31.71^{* *}$ & 0.06 & 2.22 \\
\hline Number of leaves per cutting & $0.73^{* *}$ & $113.25^{* *}$ & $11.02^{* *}$ & $10.59^{* *}$ & 0.11 & 4.55 \\
\hline Shoot length $(\mathrm{cm})$ & $0.08 \mathrm{~ns}$ & $30.94^{* *}$ & $78.73^{* *}$ & $8.81^{* *}$ & 0.19 & 5.02 \\
\hline Root length $(\mathrm{cm})$ & $0.06 \mathrm{~ns}$ & $11.40^{* *}$ & $31.17^{* *}$ & $14.65^{* *}$ & 0.20 & 6.15 \\
\hline
\end{tabular}

Table 2. Main effect of physiological ages of cuttings and genotypes on different shooting and rooting attributes of stem cuttings in Jatropha curcas

\begin{tabular}{|c|c|c|c|c|c|c|c|c|c|}
\hline Treatments & DNBO & DSD & PCS & PCR & $\mathrm{NSC}$ & NRC & NLC & SL & $\mathrm{RL}$ \\
\hline \multicolumn{10}{|l|}{ Cuttings: } \\
\hline HWC & 6.56 & 13.34 & 96.00 & 95.95 & 4.33 & 9.80 & 9.71 & 7.01 & 6.78 \\
\hline SHWC & 4.84 & 11.70 & 100.0 & 98.47 & 3.20 & 10.94 & 8.13 & 9.65 & 6.58 \\
\hline SWC & 7.36 & 11.91 & 92.06 & 90.72 & 2.66 & 11.41 & 4.36 & 9.31 & 8.18 \\
\hline LSD $(0.05)$ & 0.203 & 0.969 & 0.246 & 0.672 & 0.141 & 0.215 & 0.304 & 0.393 & 0.340 \\
\hline \multicolumn{10}{|l|}{ Genotypes: } \\
\hline $\mathrm{JC}-13$ & 5.67 & 12.19 & 95.54 & 90.69 & 3.43 & 11.07 & 6.82 & 6.40 & 6.41 \\
\hline JC-14 & 5.00 & 10.31 & 100.0 & 100.0 & 4.50 & 10.97 & 6.39 & 12.96 & 10.37 \\
\hline JC-17 & 6.70 & 12.76 & 100.0 & 100.0 & 3.38 & 11.59 & 6.59 & 10.36 & 6.66 \\
\hline JC-20 & 6.40 & 11.43 & 91.14 & 90.97 & 3.18 & 9.28 & 8.64 & 5.90 & 5.51 \\
\hline JC-21 & 7.50 & 14.89 & 93.41 & 93.58 & 2.50 & 10.69 & 8.56 & 7.69 & 6.95 \\
\hline LSD $(0.05)$ & 0.309 & 1.473 & 0.375 & 1.022 & 0.214 & 0.327 & 0.462 & 0.597 & 0.607 \\
\hline
\end{tabular}

HWC $=$ Hard wood cutting, SHWC $=$ Semi hard wood cuttings, SWC = Soft wood cuttings

$\mathrm{DNBO}=$ Days to new bud opening, $\mathrm{DSD}=$ Days to shoot development, $\mathrm{PCS}=$ Percent cuttings with shoot, $\mathrm{PCR}=$ Percent cuttings with root, NSC $=$ Number of shoots per cuttings, NRC $=$ Number of roots per cuttings, NLC $=$ Number of leaves per cutting, $\mathrm{SL}=$ Shoot length $(\mathrm{cm}), \mathrm{RL}=$ Root length $(\mathrm{cm})$ 
Table 3. Effect of physiological ages of cuttings and genotype on percent cuttings with root, number of roots per cutting, root length $(\mathrm{cm})$ in Jatropha curcas at 15, 30, 45 days after planting

\begin{tabular}{|l|l|c|c|c|c|c|c|c|c|c|}
\hline \multirow{2}{*}{ Cuttings } & \multirow{2}{*}{ Genotype } & \multicolumn{3}{|c|}{$\begin{array}{c}\text { Percent cuttings with } \\
\text { root }\end{array}$} & \multicolumn{3}{|c|}{$\begin{array}{c}\text { Numer of roots per } \\
\text { cutting }\end{array}$} & \multicolumn{3}{c|}{ Root length (cm) } \\
\cline { 3 - 12 } & & 15 & 30 & 45 & 15 & 30 & 45 & 15 & 30 & 45 \\
\hline HWC & JC-13 & 41.7 & 60.0 & 93.3 & 2.0 & 12.0 & 7.5 & 0.8 & 2.5 & 5.4 \\
\hline & JC-14 & 81.7 & 86.4 & 100 & 2.0 & 8.5 & 15.0 & 1.2 & 4.6 & 11.0 \\
\hline & JC-17 & 81.7 & 80.0 & 100 & 1.0 & 8.7 & 7.0 & 0.6 & 2.0 & 4.7 \\
\hline & JC-20 & 48.3 & 66.7 & 86.4 & 0.0 & 5.2 & 9.0 & 0.4 & 1.6 & 3.5 \\
\hline & JC-21 & 61.7 & 80.2 & 100 & 1.0 & 6.7 & 10.5 & 1.2 & 4.0 & 9.3 \\
\hline Mean & & $\mathbf{6 3 . 0}$ & $\mathbf{7 4 . 6}$ & $\mathbf{9 5 . 9}$ & $\mathbf{1 . 2}$ & $\mathbf{8 . 2}$ & $\mathbf{9 . 8}$ & $\mathbf{0 . 8}$ & $\mathbf{2 . 9}$ & $\mathbf{6 . 8}$ \\
\hline SHWC & JC-13 & 55.0 & 79.8 & 92.3 & 2.0 & 18.0 & 12.5 & 1.4 & 3.5 & 8.3 \\
\hline & JC-14 & 88.3 & 100 & 100 & 4.0 & 8.0 & 10.9 & 1.5 & 3.7 & 10.0 \\
\hline & JC-17 & 75.0 & 80.0 & 100 & 1.0 & 16.5 & 12.0 & 1.0 & 2.5 & 5.9 \\
\hline & JC-20 & 81.7 & 85.1 & 100 & 3.0 & 13.8 & 9.3 & 0.3 & 1.6 & 4.0 \\
\hline & JC-21 & 61.7 & 81.4 & 100 & 2.0 & 18.7 & 10.0 & 0.7 & 1.9 & 4.7 \\
\hline Mean & & $\mathbf{7 2 . 4}$ & $\mathbf{8 5 . 3}$ & $\mathbf{9 8 . 5}$ & $\mathbf{2 . 4}$ & $\mathbf{1 5 . 0}$ & $\mathbf{1 0 . 9}$ & $\mathbf{0 . 9}$ & $\mathbf{2 . 7}$ & $\mathbf{6 . 6}$ \\
\hline SWC & JC-13 & 55.4 & 65.6 & 86.4 & 2.0 & 15.6 & 13.2 & 0.8 & 2.3 & 5.5 \\
\hline & JC-14 & 61.6 & 100 & 100 & 1.0 & 6.2 & 7.0 & 1.5 & 4.2 & 10.1 \\
\hline & JC-17 & 61.7 & 66.3 & 100 & 3.0 & 18.4 & 15.8 & 1.5 & 3.9 & 9.4 \\
\hline & JC-20 & 55.4 & 73.6 & 86.5 & 2.0 & 13.5 & 9.5 & 1.4 & 3.7 & 9.0 \\
\hline & JC-21 & 41.3 & 73.5 & 80.7 & 3.0 & 17.5 & 11.6 & 1.0 & 3.0 & 6.9 \\
\hline Mean & & $\mathbf{5 5 . 1}$ & $\mathbf{7 5 . 8}$ & $\mathbf{9 0 . 7}$ & $\mathbf{2 . 2}$ & $\mathbf{1 4 . 2}$ & $\mathbf{1 1 . 4}$ & $\mathbf{1 . 3}$ & $\mathbf{3 . 4}$ & $\mathbf{8 . 2}$ \\
\hline
\end{tabular}

$\mathrm{HWC}=$ Hard wood cutting, $\mathrm{SHWC}=$ Semi hard wood cuttings, $\mathrm{SWC}=$ Soft wood cuttings

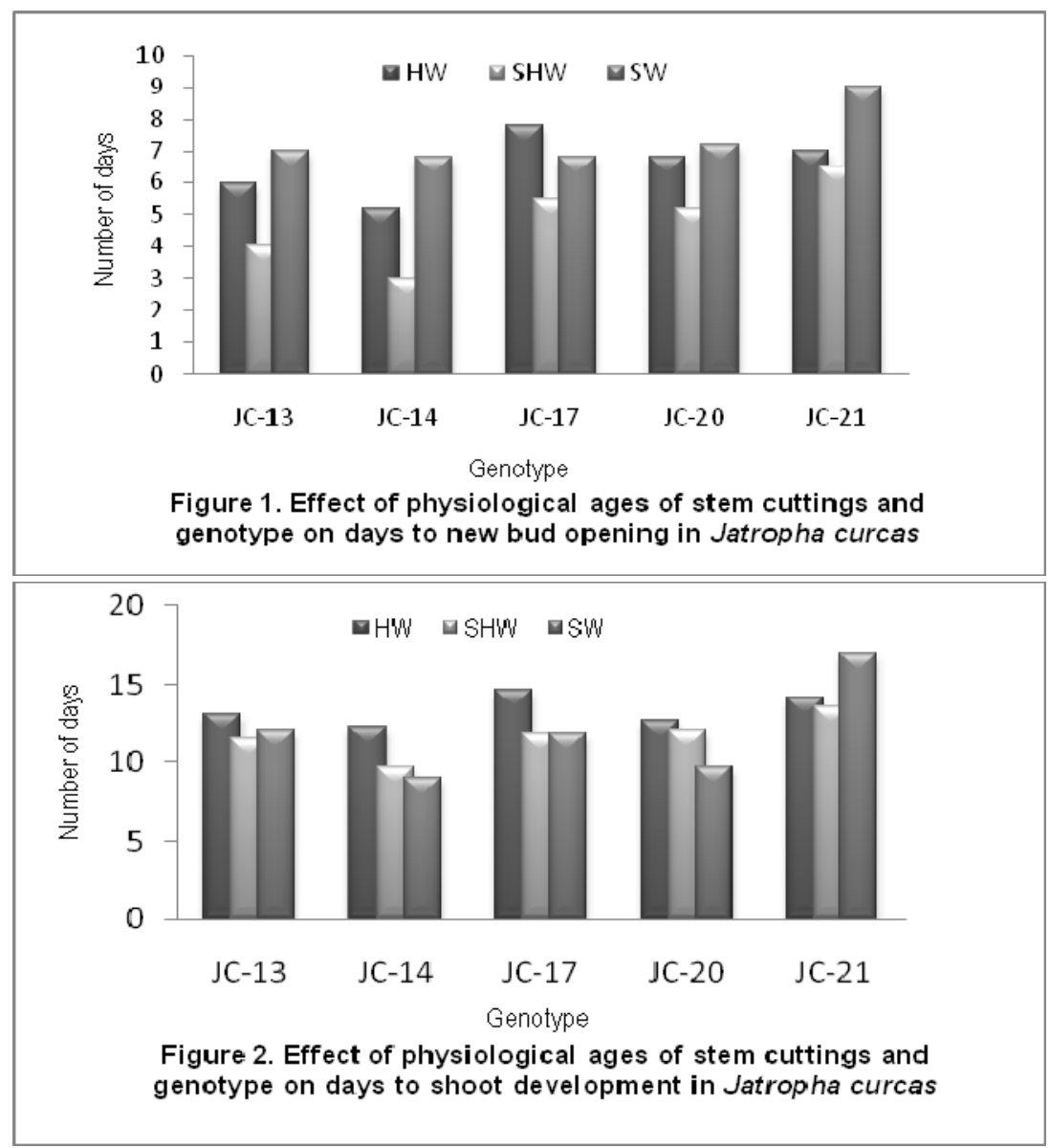




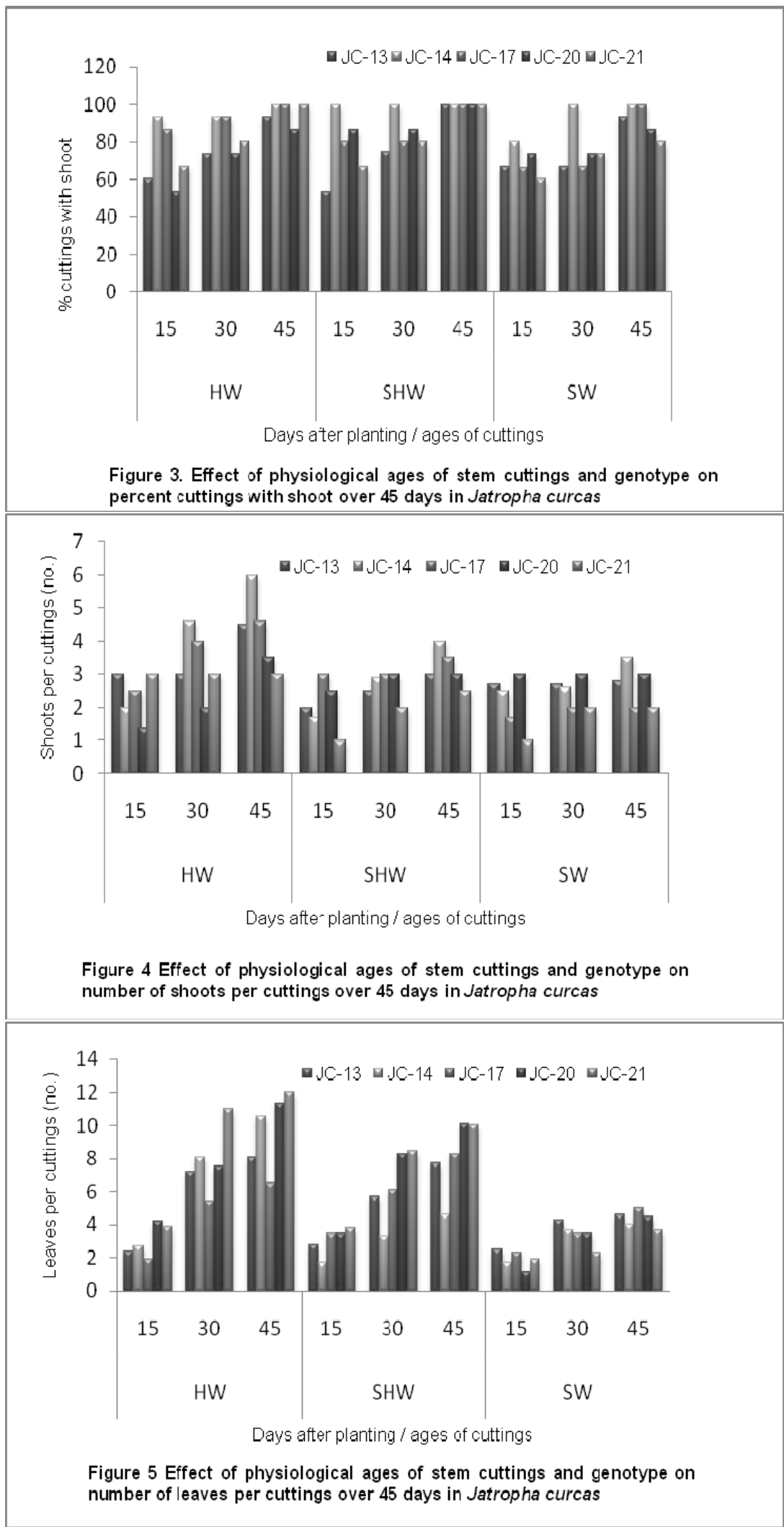




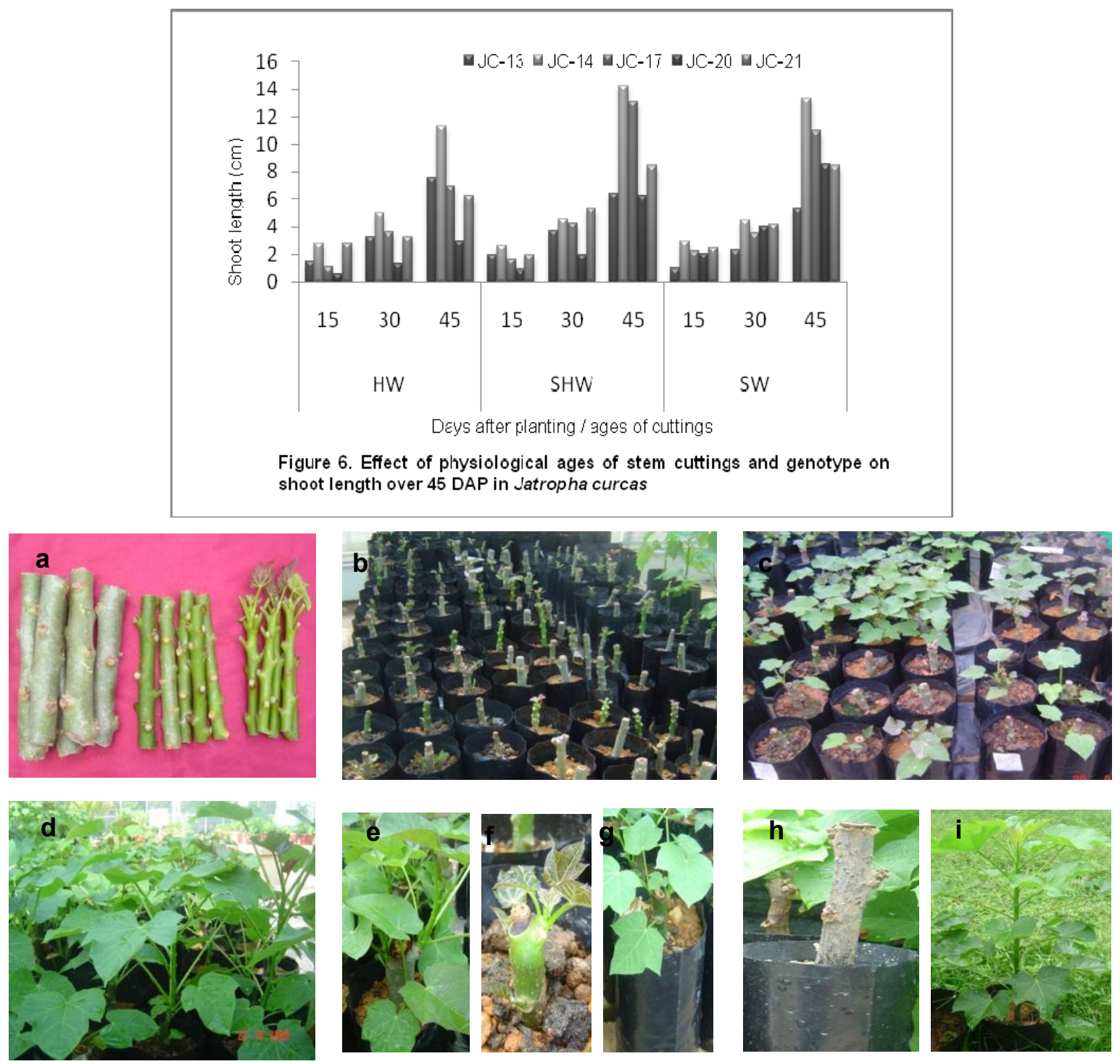

Figure 7. Showing (a) different types of cuttings (b) cuttings after 15 days of planting (c) cuttings after 30 days of planting (d) cuttings after 45 days of planting (e) shoot growth after 15 days (f) 30 days (g) 45 days of planting (h) cutting failed to continue growth (i) plant establish in polybag

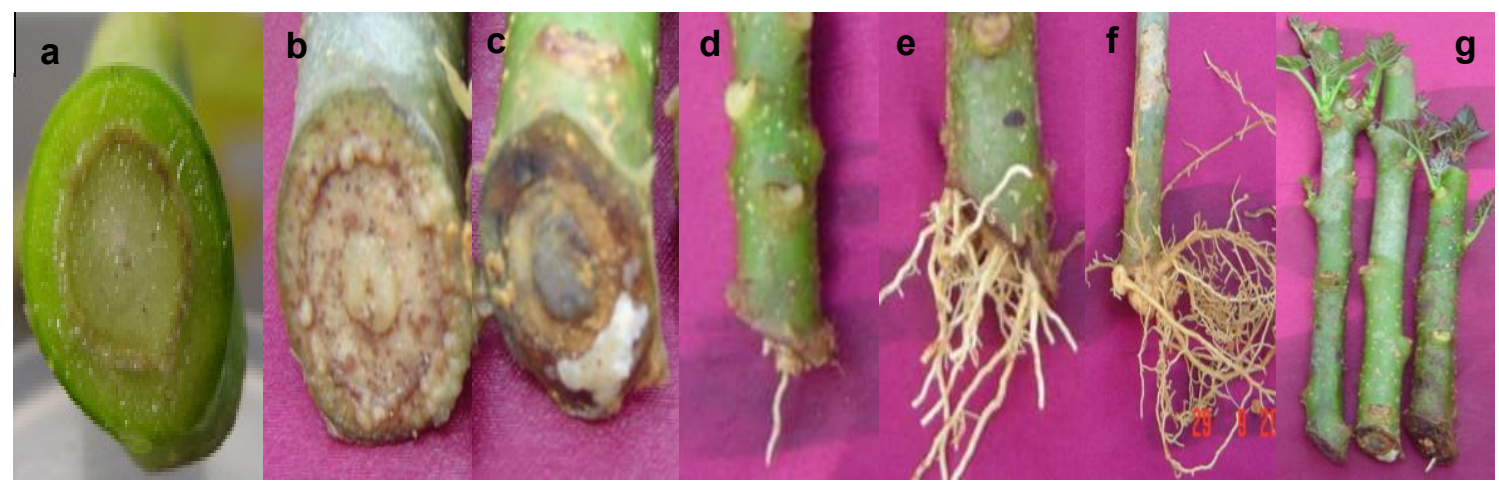

Figure 8. Development of adventitious root at the basal end of Jatropha curcas cutting (a) day 0 no changes occurred, (b) day 7 some callus developed at the basal end of cutting, (c) day 10 root primordial emerged from the callus (d) day 15 root emerged from the callus (e) root growth after 30 days (f) root growth after 45 days (g) shoot growing continue without root 